\title{
Pleural Aspergillosis: A Rare Presentation of Fungal Infection
}

\author{
Plevra Aspergillozis: Nadir Görülen Bir Mantar Enfeksiyonu
}

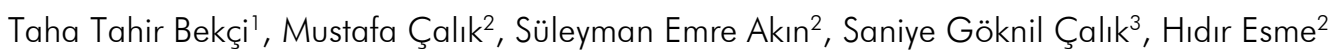

\begin{abstract}
Fungal infections accounts for less than $1 \%$ of all pleural effusions and rare causes of empyema. Herein, we report an immunosuppressed case of aspergillus empyema thoracis with pneumothorax. A 63-yearold female presented with complaints of progressive shortness of breath and right-sided chest pain. Radiological examination revealed a pneumonic consolidation in the right middle lobe. Aspergillus was grown in the sputum culture. Repeated scans showed right hydropneumothorax which was treated with intercostal drainage. She underwent surgery due to persistent air leaks, multi-loculated empyema, and unexpanded lung. Total right pleurectomy (decortication) was performed. She was discharged after 25 days on oral voriconazole which was continued for three months. It can be challenging to treat fungal empyema. Clinical suspicion and early administration of anti-fungal agents with surgical interventions kind of pleural drainage or pleurectomy may be helpful in improving the outcome.
\end{abstract}

Key words: Aspergillus, Empyema, Fungal Infections.

\section{Özet}

Mantar enfeksiyonları tüm plevral efüzyonların $\% 1$ 'den daha azından sorumludur. Nadiren ampiyeme neden olurlar. Aspegillus'a bağlı ampiyem ve pnömotoraks gelişen immünsupresif bir olguyu sunmayı amaçladık. Altmış üç yaşında kadın hastada ilerleyici bir nefes darlığı ve sağ göğüs ağrısı şikâyetleri mevcuttu. Radyolojik incelenmesinde sağ orta lobda pnömoni tespit edildi. Ampirik antibiyotik tedavisi başlandı. Balgam kültüründe aspergillus üredi. Kontrol incelemesinde sağ hidropnömotoraks tespit edilen hastaya interkostal drenai yapıldı. Hasta, uzamış hava kaçağı, mültiloküle ampiyem ve akciğerin ekspansiyon kusuru nedeniyle ameliyata alındı. Komple sağ dekortikasyon yapıldı. Ameliyat sonrası dönem sorunsuz geçti ve hastanın genel durumu düzeldi. Yirmi beş gün sonra taburcu edilen hastaya üç ay boyunca ağızdan vorikonazol tedavisi verildi. Fungal enfeksiyonların tedavisi zor olabilmektedir. Klinik şüphe, erken antifungal tedavi, plevral drenai ve plevrektomi gibi cerrahi müdahalelerle iyi sonuçlar alınabilir.

Anahtar Sözcükler: Aspergillus, Ampiyem, Fungal Enfeksiyonlar.
'Department of Pulmonary Medicine, Konya Education and Research Hospital, Konya, Turkey

${ }^{2}$ Department of Thoracic Surgery, Konya Education and Research Hospital, Konya, Turkey

${ }^{3}$ Department of Emergency Medicine, Konya Education and Research Hospital, Konya, Turkey

\author{
'Konya Eğitim ve Araşsırma Hastanesi, Göğüs Hastalıkları \\ Kliniği, Konya \\ ${ }^{2}$ Konya Eğitim ve Araştırma Hastanesi, Göğüs Cerrahisi \\ Kliniği, Konya \\ ${ }^{3}$ Konya Eğitim ve Araştırma Hastanesi, Acil Tıp Kliniği, Konya
}

Submitted (Başvuru tarihi): 30.12.2015 Accepted (Kabul tarihi): 29.02.2016

Correspondence (iletişim): Mustafa Çalık, Department of Thoracic Surgery, Konya Education and Research Hospital, Konya, Turkey

e-mail:drmcalik@hotmail.com 
Fungal infections accounts for less than 1\% of all pleural effusions and rare causes of empyema (1). Most of them are caused by the Candida species particularly in critically ill patients with a high mortality (2). The aspergillus empyema, one of the causes of fungal infections of the pleu$\mathrm{ra}$, is an uncommon clinical entity with a high mortality often due to delayed or overlooked diagnosis and inefficient treatment. It was first described by Cleland in 1924. Aspergillosis is a large spectrum of diseases caused by members of the Aspergillus genus. Aspergillus fumigatus is the most commonly isolated species, followed by Aspergillus flavus and Aspergillus niger (3). Aspergillus has two forms, including conidiophores and hyphae. The fungus may grow in water, soil, some animals and plant materials. Infection of the lung is usually caused by direct inhalation of the spores. Although rare, it usually occurs in the presence of pre-existing lung disease or surgery such as pre-existing tuberculosis (87\%), bronchopulmonary fistulas (74\%), pleural drainage (56\%), and lung resection (17\%). Pleural aspergillosis is not characteristically associated with pulmonary aspergillosis in either its allergic, bronchopneumonic, or intracavitary forms (3-5). Herein, we report a case of aspergillus empyema thoracis with pneumothorax in an immunosuppressed patient.

\section{CASE}

A 63-year-old female presented with complaints of progressive shortness of breath and right-sided chest pain. She was being followed for hypothyroidism, sarcoidosis, primary hyperparathyroidism, and hypopituitarism due to granulomatous hypophysitis. She was previously used corticosteroids for two months. Thoracic computed tomography (CT) showed pneumonic consolidation in the right middle lobe (Figure 1). She was treated with antibiotics empirically for a short time of period, including imipenem. Bacterial cultures were sterile. There was Aspergillus spp. cultured sputum and intravenous voriconazole was initiated with a loading dose of $400 \mathrm{mg}$ twice on the first day, followed by 200 mg twice daily. Her symptoms including dyspnea and chest wall pain improved after a two-week antifungal treatment. Repeated CT scan showed right hydropneumothorax in the right pleural space with pleural thickening (Figure 2). After the chest tube placement, purulent fluid drainage and massive air leak were seen. Pleural fluids were sent for bacteria, tuberculosis, and fungal cultures. Subsequently, Aspergillus spp. was grown in the pleural fluid culture. Pulmonary parenchyma did not expand enough to fill the space. Thus, the patient underwent surgery due to persistent air leaks, multi-loculated empyema, and unexpanded lung. Complete right pleurectomy was done through the muscle sparing thoracotomy. The presence of Aspergillus hyphae was pathologically confirmed. The postoperative period was uneventful and her overall condition improved gradvally. The patient was discharged after 25 days on oral voriconazole which was continued for three months. No side effects were noted. After four-month follow-up, the patient was still alive without recurrence.

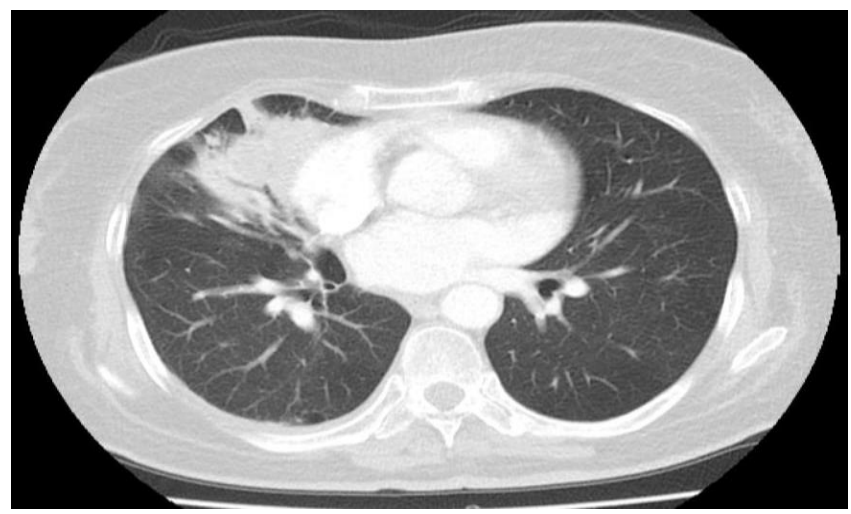

Figure 1: Thoracic CT on admission showing right Pneumonic consolidation

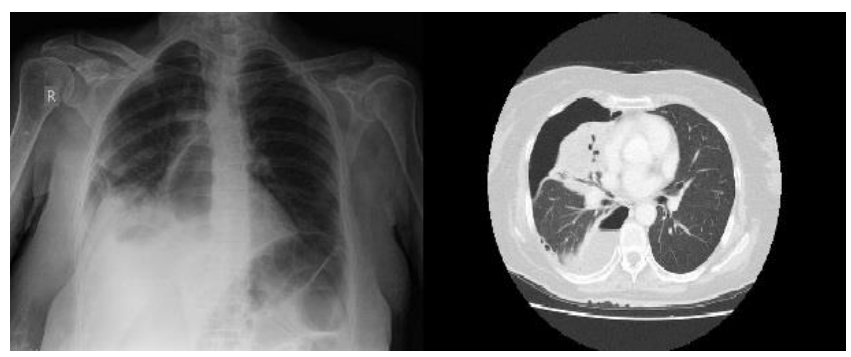

Figure 2: Repeated anteroposterior view of the chest $X$-ray and Thoracic CT showing right hydropneumothorax in the right pleural space with pleural thickening

\section{DISCUSSION}

Three distinctive patterns of aspergillus-related lung diseases are recognized: saprophytic infestation of airways, cavities and necrotic tissue e.g. aspergillomas; allergic manifestations such as extrinsic allergic alveolitis, asthma, allergic bronchopulmonary aspergillosis, bronchocentric granulomatosis and chronic eosinophilic pneumonia; and airway and tissue invasive disease called invasive aspergillosis (5). Patients who have Aspergillosis infection usually are immunocompromised, as in our case. The predisposing factors are diabetes, prior tuberculosis infection, chronic lung disease, receiving chemotherapy, and posttransplantation state (6). Management of aspergillosis empyema is very difficult, as it requires treatment over several months, particularly in patients with the following factors: diabetes, glucocorticoid therapy, chemotherapy, 
acquired immune deficiency syndrome, hematologic malignancies (6) previous hospitalizations especially in ICUs, pre-existing pulmonary tuberculosis, bronchopleural fistula, pleural intubation or drainage, and lung resection $(3,5)$.

There are many treatment options, including antifungal chemotherapy and surgical procedures. Although amphotericin $B$ is the mainstay of the conventional antifungal medications, miconazole and nystatin can be used (3). However, due to its toxicity such as nephrotoxicity, phlebitis, hypokalemia, hypomagnesaemia, and anemia in $80 \%$ of cases, its use is limited. Voriconazole, one of the novel anti-fungals, is better tolerated than amphotericin B and is a broad-spectrum triazole which is active against Aspergillus species. However, the success rates continue to be low, only 20 to $27 \%$, due to poor premorbid state and delayed diagnosis (5). In addition, systemic treatment has a limited response in patients with fungal empyema, as the pleural surface is thicker, the pleural fluid is more acidic, and more purulent fluid due to inflammation and an increased protein flux are present in the pleural space than in other conditions (7). Therefore, even in the longterm anti-fungal treatment of pleural Aspergillosis without surgery will probably fail, in particular, in patients with invasive Aspergillosis. Surgery is currently the treatment of choice in combination with anti-fungal drugs with considerable postoperative morbidity and mortality rates (8). In conclusion, as removing surgically all the Aspergillosisinfected material is not possible and it can be difficult to treat fungal empyema, surgical intervention can provide an effective cure or faster recovery, despite all risks originating from its own. Anti-fungal medications, including intravenous voriconazole or amphotericin, should be considered with surgery in invasive fungal infections. As shown in our case, empyema of a fungal origin is associated with high mortality rates; however, clinical suspicion and early administration of anti-fungal agents with surgical interventions kind of pleural drainage or pleurectomy may be helpful in improving the outcome.

\section{CONFLICTS OF INTEREST}

None declared.

\section{AUTHOR CONTRIBUTIONS}

Concept - T.T.B., M.Ç., S.E.A., S.G.Ç., H.E.; Planning and Design - T.T.B., M.Ç., S.E.A., S.G.Ç., H.E.; Supervision - T.T.B., M.Ç., S.E.A., S.G.Ç., H.E.; Funding - M.Ç., S.G.Ç.; Materials - M.Ç., S.G.Ç.; Data Collection and/or Processing - M.Ç., S.G.Ç.; Analysis and/or Interpretation - M.Ç., S.G.Ç.; Literature Review - M.Ç., S.G.Ç.; Writing - M.Ç., S.G.Ç.; Critical Review - M.Ç., S.G.Ç.

\section{YAZAR KATKILARI}

Fikir - T.T.B., M.Ç., S.E.A., S.G.Ç., H.E.; Tasarım ve Dizayn - T.T.B., M.Ç., S.E.A., S.G.Ç., H.E.; Denetleme T.T.B., M.Ç., S.E.A., S.G.Ç., H.E.; Kaynaklar - M.Ç., S.G.Ç.; Malzemeler - M.Ç., S.G.Ç.; Veri Toplama ve/veya İşleme - M.Ç., S.G.Ç.; Analiz ve/veya Yorum M.Ç., S.G.Ç.; Literatür Taraması - M.Ç., S.G.Ç.; Yazıyı Yazan - M.Ç., S.G.Ç.; Eleştirel İnceleme - M.Ç., S.G.Ç.

\section{REFERENCES}

1. Light RW. Pleural effusion secondary to fungal infections, actinomycosis, and nocardiosis. In: Light RW ed. Pleural Diseases. 4th ed. Philadelphia: Lippincott Williams \& Wilkins; 2001:196-203. [CrossRef]

2. Purohit M, Guleri A, Zacharias J. Salvage therapy with topical antifungal for Aspergillus fumigatus empyema complicating extrapleural pneumonectomy. Interact Cardiovasc Thorac Surg 2012; 15:518-9. [CrossRef]

3. Bhatnagar T, Bhatnagar AK. Pleural Aspergillosis in an otherwise healthy Individual. Lung India 2014; 31 :155-7. [CrossRef]

4. Chen CH, Ho-Chang, Liu HC, Tsung TT, Hung TT. Spontaneous empyema necessitates caused by Aspergillus fumigatus in an immunocompetent patient. JRSM Short Rep $2011 ; 2: 25$. [CrossRef]

5. Goel MK, Juneja D, Jain SK, Chaudhuri S, Kumar A. A rare presentation of aspergillus infection as empyema thoracis. Lung India 2010; 27:27-9. [CrossRef]

6. Samarakoon P, Soubani A. Invasive pulmonary aspergillosis in patients with COPD: a report of five cases and systematic review of the literature. Chron Respir Dis 2008, 5:19-27. [CrossRef]

7. Teixeira LR, Sasse SA, Villarino MA, Nguyen T, Mulligan $M E$, Light RW. Antibiotic levels in empyemic pleural fluid. Chest 2000; 117:1734-9. [CrossRef]

8. Ramos R, Rodríguez L, Saumench J, Iborra E, Cairols MA, Dorca J. Endovascular management of a left subclavian artery lesion following thoracoplasty for bronchopleural fistula and empyema secondary to aspergillus fumigatus. Arch Bronconeumol 2008; 44:338-40. [CrossRef] 